\title{
The involvement of hypoxia-inducible factor 1 alpha in Toll-like receptor 7/8-mediated inflammatory response
}

\author{
Sally A Nicholas ${ }^{1}$, Vadim V Sumbayev ${ }^{1}$ \\ ${ }^{I}$ Medway School of Pharmacy, University of Kent, Kent ME4 4TB, UK
}

Toll-like receptors (TLRs) 7 and 8 are crucial in host defence against single-stranded RNA (ssRNA) viruses. Such viruses cause severe illnesses, which remain a serious medical burden in both industrialised and developing countries. TLR7/8 downstream signaling leads to a dramatic cellular stress associated with energy consumption. However, the molecular mechanisms of cell survival and adaptation to TLR7/8-induced stress, which give the cells an opportunity to initiate proper inflammatory reactions, are not clear at all. Here we report for the first time that ligand-induced ac-

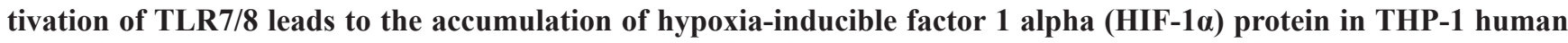
myeloid macrophages via redox- and reactive nitrogen species-dependent mechanisms. MAP kinases and phosphoinositol-3K are not involved in TLR7/8-mediated HIF-1 $\alpha$ accumulation. Experiments with HIF-1 $\alpha$ knockdown THP1 cells have clearly demonstrated that HIF-1 $\alpha$ is important for the protection of these cells against TLR7/8-induced depletion of ATP. Thus, HIF-1 $\alpha$ might support both cell survival and the production of pro-inflammatory cytokines upon TLR7/8 activation.

Keywords: inflammation and innate immunity, Toll-like receptors, HIF-1 protein, apoptosis Cell Research (2009) 19:973-983. doi: 10.1038/cr.2009.44; published online 21 April 2009

\section{Introduction}

Human innate immune responses to infections are initiated via recognition of pathogen-associated molecular patterns by specific receptors. Toll-like receptors (TLRs) are the key pattern recognition receptors that allow cells to specifically detect pathogens by recognising the components shared by many viruses, bacteria and fungi [1]. TLRs lie at the core of resistance to disease, initiating most of the phenomena that occur in the course of infection. TLRs 7 and 8 are crucial in defence against singlestranded RNA (ssRNA) viruses [2], such as human immunodeficiency virus 1 (HIV-1), influenza virus, hepatitis $\mathrm{C}$ virus and many others. These viruses cause severe illnesses, resulting in significant morbidity and mortality in both industrialised and developing countries. TLR7/8 are endosomal receptors [3] expressed in various cell types, including myeloid macrophages and neutrophils $[4$,

Correspondence: Vadim V Sumbayev

Tel: +44-1634-883-868; Fax +44-1634-883-927

E-mail: V.Sumbayev@kent.ac.uk

Received 1 February 2009; revised 3 February 2009; accepted 24 February 2009; published online 21 April 2009
5]. They specifically recognise viral ssRNA [2], with subsequent activation of downstream signaling pathways resulting in the expression and release of pro-inflammatory cytokines [1]. TLR7/8 downstream signaling leads to a dramatic cellular stress associated with energy consumption. However, the molecular mechanisms of cell survival and adaptation to TLR7/8-induced stress, which give the cells an opportunity to initiate proper inflammatory reactions, are not clear at all. Recently it has been found that signaling by membrane-associated TLR4, which specifically recognises lipopolysaccharide (LPS) shared by Gram-negative bacteria, induces the accumulation of hypoxia-inducible factor 1 alpha (HIF-1 $\alpha$ ) [6]. HIF-1 $\alpha$ is the inducible subunit of the heterodimeric HIF-1 transcription complex, which consists of two subunits, HIF$1 \alpha$ and HIF-1 $\beta$ [7]. HIF- $1 \alpha$ is rapidly accumulated in cells exposed to hypoxia or several types of non-hypoxic stimuli, such as inflammatory mediators, cytokines, reactive oxygen (ROS) and nitrogen (RNS) species $[7,8]$. Otherwise HIF-1 $\alpha$ protein undergoes rapid ubiquitination followed by proteasomal degradation [9]. LPS induces accumulation of HIF- $1 \alpha$ protein via NADPH oxidase (Nox)-associated cross-talk with the mitogen-activated protein (MAP) kinase cascade [6]. In general, HIF-1 $\alpha$ 
as a transcription factor, plays a pivotal role in mediating angiogenesis, glycolysis and cell adhesion [10], which are critical for inflammation. However, it was found that HIF- $1 \alpha$ protein is an essential factor for protection of myeloid cells against LPS-induced depletion of ATP and apoptosis [11], a fact that is crucial for TLR4-mediated production of pro-inflammatory cytokines. Based on these data, one could hypothesize that HIF- $1 \alpha$ protein might also be involved in TLR7/8 downstream signaling. However, if so, then different mechanisms of its stabilisation might apply given the endosomal localisation of these receptors.

Here we report for the first time that exposure of THP-1 human myeloid macrophages to resiquimoid (R848, the specific synthetic TLR7/8 ligand) induced HIF- $1 \alpha$ accumulation in a time- and concentrationdependent manner. Similar results were observed in cells transfected with the uridine-rich ssRNA fragment of the HXB2 region of HIV-1. Pre-treatment of cells with tyrosine kinase inhibitor genistein, phosphoinositol (PI)specific PLC- $1 \gamma$ inhibitor U73122, PKC $\alpha / \beta$ inhibitor Gö6983, Nox inhibitor diphenyleneiodonium chloride (DPI) and ROS scavenger $N$-acetylcysteine (NAC), followed by stimulation with $\mathrm{R} 848$, resulted in attenuation of ROS generation and HIF- $1 \alpha$ accumulation. Pre-treatment of the cells with a specific inhibitor of interferon and interleukin-associated kinases 1 and 4 (IRAK1/4) did not affect ROS production and HIF- $1 \alpha$ accumulation at early stages of R848 exposure. However, this inhibitor attenuated both effects at later stages of exposure to R848, confirming recent evidence about IRAK1/4dependent activation of Nox [12]. A decrease in HIF$1 \alpha$ accumulation also occurred following pre-treatment with the nitric oxide synthase (NOS) inhibitor, $N$-monomethyl arginine (NMMA). However, transfection of THP-1 cells with the dominant-negative form of ASK1 (ASK1-KM) or pre-treatment with SB203580, a specific p38 MAP kinase inhibitor, had no effect on R848induced HIF- $1 \alpha$ accumulation. These data suggest that TLR7/8-dependent accumulation of HIF- $1 \alpha$ protein is achieved via redox- and RNS-dependent mechanisms. This indicates that membrane-associated TLR4 and endosomal TLR7/8 utilize different mechanisms for HIF$1 \alpha$ accumulation, since the ASK1-p38 pathway does not play any role in R848-induced HIF- $1 \alpha$ accumulation but is crucial in the case of TLR4 signaling [6]. In addition, we have shown that HIF-1 $\alpha$ knockdown with siRNA in THP-1 myeloid macrophages leads to a depletion of ATP, a decrease in R848-induced production of interleukin-6 (IL-6) and tumour necrosis factor alpha (TNF $\alpha$ ), and a significant increase in caspase- 3 activity. This phenotype was reversed (restoration of IL-6/TNF $\alpha$ production and decrease in caspase-3 activity) via treatment of HIF-1 $\alpha$ knockdown cells with extracellular ATP. This suggests that HIF- $1 \alpha$ is important for the protection of THP-1 cells against TLR7/8-induced depletion of ATP, and therefore might support cell survival and the production of pro-inflammatory cytokines.

\section{Results}

TLR7/8 ligands induce accumulation of the HIF-1 $\alpha$ protein

TLR7/8 downstream intracellular signaling cascades induced by viral ssRNA lead to cellular stress. However, the molecular mechanisms by which the effector cells adapt to such stress, support energy metabolism and promote cell survival are not clear. Since survival of the cells, which is crucial for the expression of proinflammatory cytokines, is associated with increased oxygen consumption, we hypothesised the involvement of HIF- $1 \alpha$ protein in TLR7/8-mediated signaling. First of all, we looked for possible HIF-1 $\alpha$ accumulation/activation in THP-1 human myeloid macrophages stimulated with R848-a specific ligand of TLRs 7 and 8. Cells were stimulated for $4 \mathrm{~h}$ with $0.01,0.1,1$ and $10 \mu \mathrm{g} / \mathrm{ml}$ of R848, followed by analysis of HIF- $1 \alpha$ accumulation and its DNA-binding activity. It was found that all concentrations of R848 tested induced accumulation of HIF$1 \alpha$ protein; the highest level of accumulation occurred in the cells exposed to $0.1 \mu \mathrm{g} / \mathrm{ml}$ of R848 as measured by western blot. The levels of TLRs 7 and 8 remained unchanged. An increase in HIF-1 DNA-binding activity was also observed (Figure 1A).

R848-induced accumulation of HIF- $1 \alpha$ was comparable with that induced by the well-known HIF-1 $\alpha$ stabiliser cobalt chloride (Figure 1A). Exposure of the THP-1 cells to R848 or cobalt chloride led to an increase in the mRNA of vascular endothelium growth factor (VEGF) - the downstream target gene of the HIF-1 transcription complex.

Exposure of the cells to $1,10,10^{2}, 10^{3}$ and $10^{4} \mathrm{nM}$ of the ssRNA fragment of the HXB2 region of HIV-1 (the natural ligand of TLR7/8) resulted in HIF-1 $\alpha$ accumulation, in a concentration-dependent manner (Figure 1B). In addition, the protein levels of TLR7/8 were also not affected.

To investigate whether TLR7/8 ligands influence the transcription of HIF- $1 \alpha$, we exposed THP-1 cells to 0.1 $\mu \mathrm{g} / \mathrm{ml} \mathrm{R} 848$ or $10^{4} \mathrm{nM}$ ssRNA and performed RT-PCR to investigate changes in the level of HIF-1 $\alpha$ mRNA. In both cases we observed a clear increase in HIF-1 $\alpha$ mRNA (Figure 1C).

Both R848 and the ssRNA fragment were able to 
A

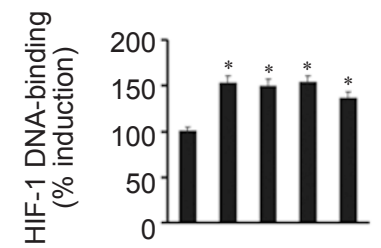

HIF-1 $\alpha$

(\% $0.1 \mu \mathrm{m} / \mathrm{ml}$ R848)

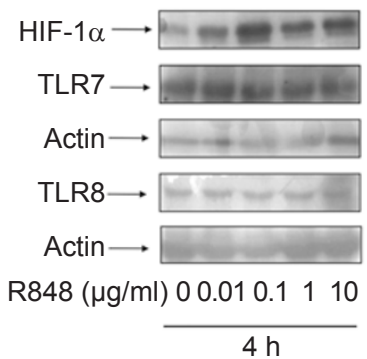

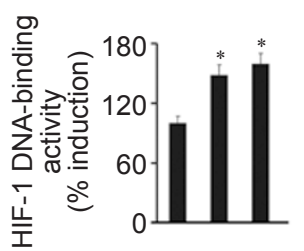

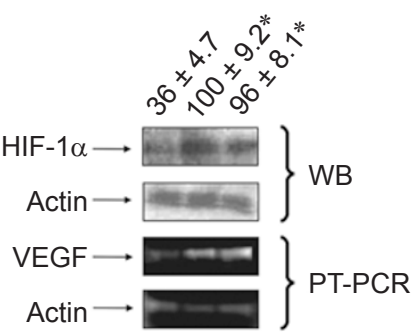

$\operatorname{R848}(0.1 \mu \mathrm{g} / \mathrm{ml})++$

$\mathrm{CoCl}_{2}(50 \mu \mathrm{M})--+$

B
HIF-1 $\alpha$

(\% $10^{4} \mathrm{nM}$ ssRNA)

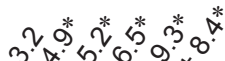

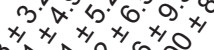

उती की की की

HIF-1 $\alpha \longrightarrow$ 1

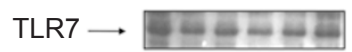

TLR8 $\rightarrow$

Actin $\longrightarrow \quad 4--=-0$

ssRNA [nM] $011010^{2} 10^{3} 10^{4}$

$4 \mathrm{~h}$

C

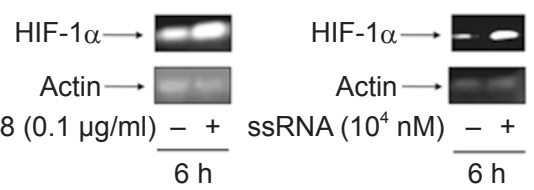

Figure 1 R848 and ssRNA induce accumulation and expression of HIF-1 $\alpha$ protein in a concentration-dependent manner. (A) THP-1 cells were stimulated for $4 \mathrm{~h}$ with $0.01,0.1,1$ and $10 \mu \mathrm{g} / \mathrm{ml} \mathrm{R} 848$, and accumulation and DNA-binding activity of HIF$1 \alpha$ protein were measured by western blot and ELISA (DNA-binding activity of HIF-1 in non-treated cells was calculated as $100 \%$ ), respectively. In addition, THP-1 cells were stimulated with $0.1 \mu \mathrm{g} / \mathrm{ml} \mathrm{R848}$ or $50 \mu \mathrm{M}$ cobalt chloride for $4 \mathrm{~h}$, and accumulation and DNA-binding activity of HIF-1 $\alpha$ protein were analysed. The level of VEGF mRNA was detected by RT-PCR after $8 \mathrm{~h}$ of treatment. (B) THP-1 cells were treated for $4 \mathrm{~h}$ with $1,10,10^{2}, 10^{3}$ and $10^{4} \mathrm{nM}$ ssRNA and accumulation (western blot) of HIF-1 $\alpha$ protein was assayed. TLR7/8 levels were also monitored and actin staining was used as a protein loading control in all western blot experiments. (C) THP-1 cells were exposed to $0.1 \mu \mathrm{g} / \mathrm{ml} \mathrm{R} 848$ or $10^{4} \mathrm{nM}$ ssRNA for $6 \mathrm{~h}$ and mRNA levels were determined by RT-PCR. The level of actin mRNA was used as a loading control. Digital data are mean values \pm SD of at least four individual experiments. $* P<0.01$ vs control. All western blot and RT-PCR data are from one experiment representative of three that gave similar results. Results of densitometric analysis of the western blot data are expressed as mean values $\pm \mathrm{SD}$, where $n=3 ; * P<0.01$ vs control.
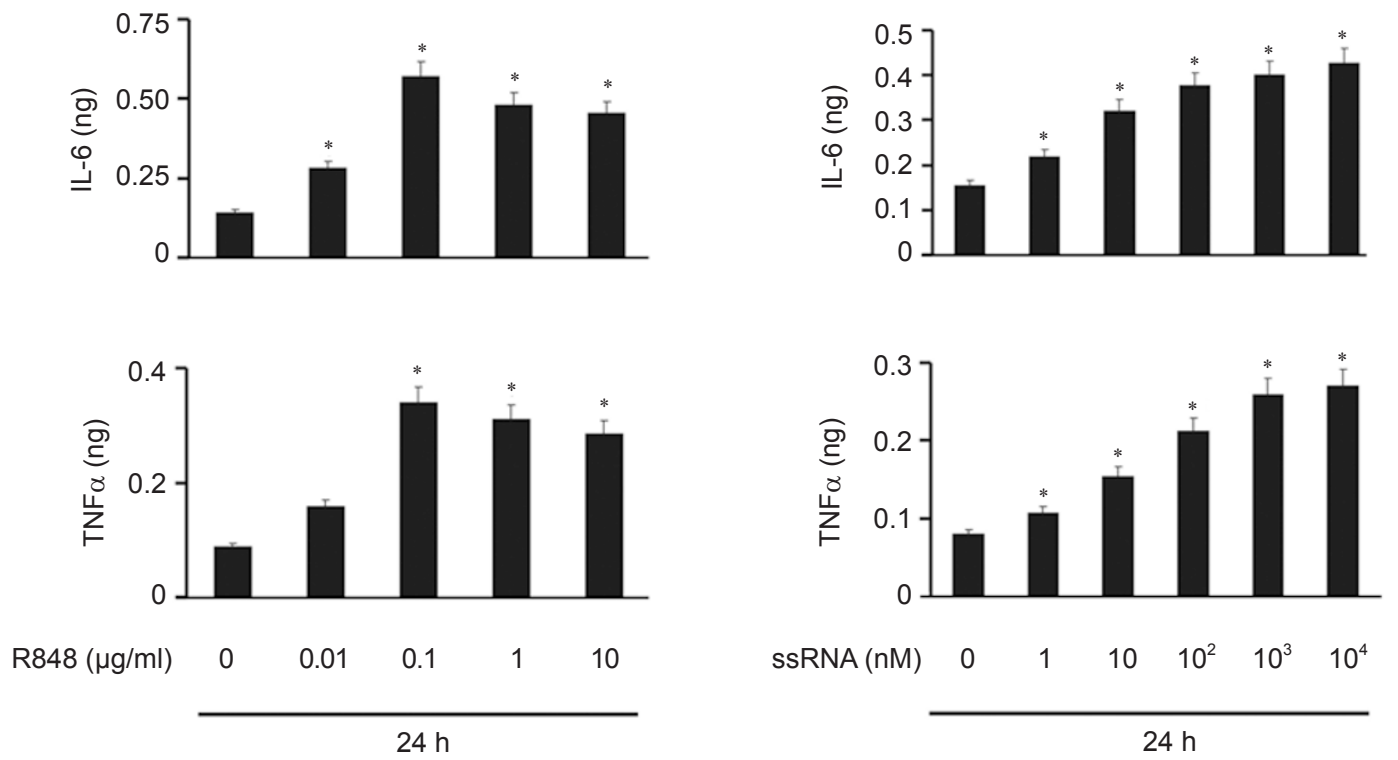

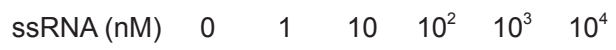

$24 \mathrm{~h}$

Figure 2 R848 and ssRNA induce release of IL- 6 and TNF $\alpha$. THP-1 cells were treated for $24 \mathrm{~h}$ with $0.01,0.1,1$ and $10 \mu \mathrm{g} / \mathrm{ml}$ R848 or $1,10,10^{2}, 10^{3}$ and $10^{4} \mathrm{nM}$ ssRNA and the release of IL- 6 and TNF $\alpha$ was analysed by ELISA. The absolute values representing the quantities of the cytokines released are expressed in $\mathrm{ng}$. Data are mean values $\pm \mathrm{SD}$ of at least four individual experiments. $* P<0.01$ vs control. 
A
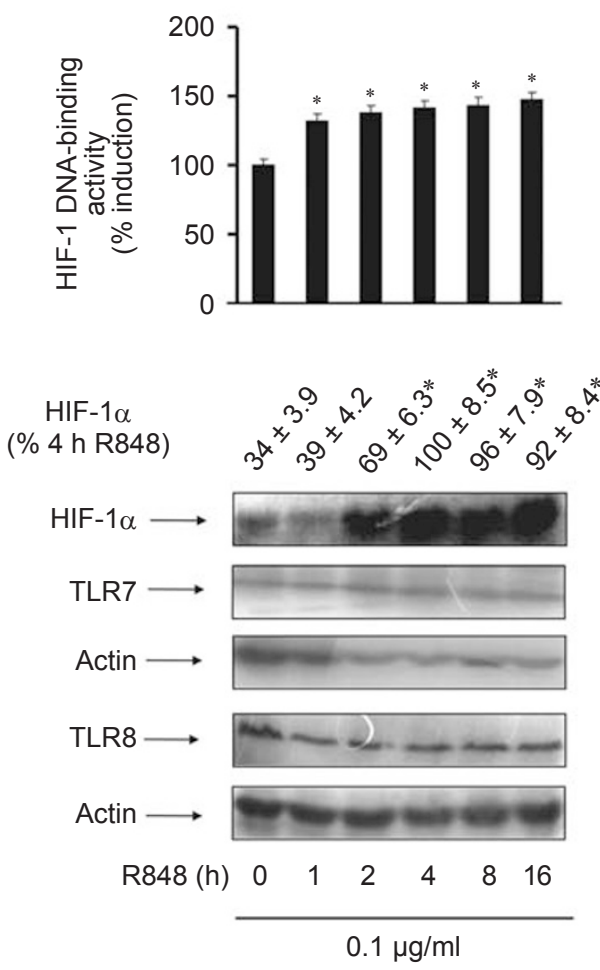

B

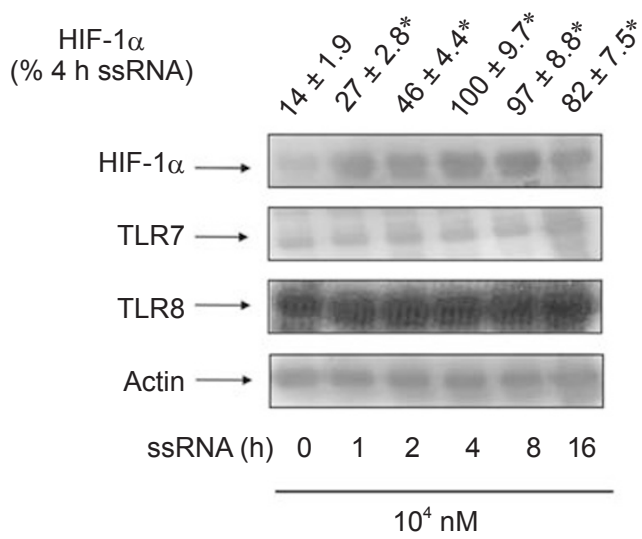

Figure 3 R848 and ssRNA induce accumulation of HIF-1 $\alpha$ protein in a time-dependent manner. (A) THP-1 cells were stimulated with $0.1 \mu \mathrm{g} / \mathrm{ml} \mathrm{R} 848$ for $1,2,4,8$ and $16 \mathrm{~h}$, and accumulation and DNA-binding activity of HIF-1 $\alpha$ protein were measured by western blot and ELISA (DNA-binding activity of HIF-1 in nontreated cells was calculated as $100 \%$ ), respectively. (B) THP-1 cells were treated with $10^{4} \mathrm{nM}$ ssRNA for $1,2,4,8$ and $16 \mathrm{~h}$ and accumulation (western blot) of HIF-1 $\alpha$ protein was assayed. TLR7/8 levels were also monitored and actin staining was used as a protein loading control in all western blot experiments. Digital data are mean values $\pm \mathrm{SD}$ of at least four individual experiments. $* P<0.01$ vs control. All western blot data are from one experiment representative of three that gave similar results. Results of densitometric analysis of the western blot data are expressed as mean values $\pm \mathrm{SD}$, where $n=3$; $* P<0.01$ vs control. induce an inflammatory reaction in THP-1 cells at the concentrations used. This was confirmed by a significant increase in the release of the pro-inflammatory cytokines IL-6 and TNF $\alpha$ in both cases (Figure 2).

Further analysis was conducted using $0.1 \mu \mathrm{g} / \mathrm{ml} \mathrm{R} 848$. THP- 1 cells were treated with this concentration of R848 for $1,2,4,8$ and $16 \mathrm{~h}$. It was found that HIF-1 $\alpha$ starts accumulating and displaying DNA-binding activity after $1 \mathrm{~h}$. The protein accumulation peaked after $4 \mathrm{~h}$ of exposure to R848. The DNA-binding activity of HIF-1 $\alpha$ protein increased in a time-dependent manner (Figure 3A). Treatment of the THP- 1 cells with $10^{4} \mathrm{nM}$ ssRNA also resulted in HIF-1 $\alpha$ protein accumulation after $1 \mathrm{~h}$. Once again, ssRNA-induced HIF-1 $\alpha$ accumulation peaked at $4 \mathrm{~h}$, after which it decreased (Figure 3B). No changes in the amounts of TLR7/8 were observed in both cases (Figure 3).

\section{TLR7/8 trigger HIF-1 $\alpha$ accumulation via redox- and} RNS-dependent mechanisms

Since TLR7/8 are associated with the MyD88 adaptor, which is known to promote generation of ROS and RNS $[2,6,13]$, we hypothesised that redox- and RNS-dependent mechanisms may be employed in TLR7/8-induced accumulation of HIF- $1 \alpha$ protein. Signaling pathways induced by some TLRs, including TLR7/8, lead to the activation of tyrosine kinases, such as Bruton's tyrosine kinase (Btk) [14], that interact with MyD88, which binds to the TLR TIR domain. This leads to the activation of various transcription factors and subsequent downstream signaling. Conversely, Btk and other tyrosine kinases have been shown to activate PLC- $1 \gamma$, leading to the release of diacylglycerols (DAG) and PI, with subsequent increase in intracellular $\mathrm{Ca}^{2+}$ levels $[15,16]$. DAG and $\mathrm{Ca}^{2+}$ cause $\mathrm{PKC} \alpha / \beta$ activation, with the eventual phosphorylation of $\mathrm{p} 47_{\text {phox }}[16,17]$, and the assembly/activation of the Nox complex that generates superoxide radicals. To test the involvement of this pathway in TLR7/8induced HIF- $1 \alpha$ accumulation, we pre-treated THP-1 cells with $30 \mu \mathrm{M}$ genistein (tyrosine kinase inhibitor), 30 $\mu \mathrm{M}$ U73122 (PLC-1 $\gamma$ inhibitor), $70 \mathrm{nM}$ Gö6983 (PKCa/ $\beta$ inhibitor), $30 \mu \mathrm{M}$ DPI (Nox inhibitor) or $1 \mathrm{mM} \mathrm{NAC}$ (the ROS scavenger) for $1 \mathrm{~h}$, followed by $4 \mathrm{~h}$ of stimulation with $0.1 \mu \mathrm{g} / \mathrm{ml} \mathrm{R} 848$. All inhibitors listed caused a reduction in R848-induced HIF- $1 \alpha$ accumulation. R848induced ROS generation was also affected by these inhibitors (Figure 4A). These results confirm that Nox and the Nox-activating pathway are involved in TLR7/8induced HIF- $1 \alpha$ accumulation.

To investigate the involvement of RNS in TLR7/8dependent HIF-1 $\alpha$ stabilisation, THP-1 cells were pretreated with $100 \mu \mathrm{M}$ NMMA (NOS inhibitor), followed 
A
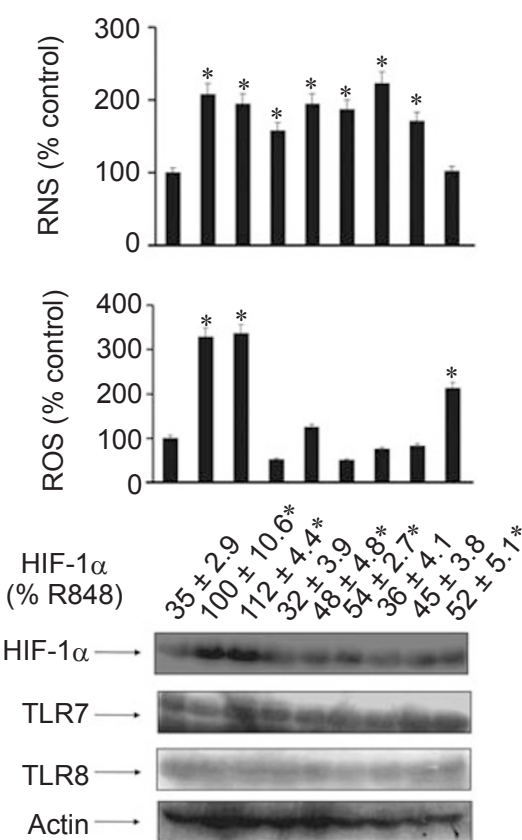

$\operatorname{R848}(0.1 \mu \mathrm{g} / \mathrm{ml})-++++++++$

SB203580 $(10 \mu \mathrm{M})-\ldots+----$

Genistein $(30 \mu \mathrm{M})-\ldots++-\ldots$

$\mathrm{U} 73122(30 \mu \mathrm{M})$ - - -++-

Gö6983 (70 nM) - - - + + - -

DPI $(30 \mu \mathrm{M})-\ldots$

$\operatorname{NAC}(1 \mathrm{mM})--\ldots+-+$

$\operatorname{NMMA}(100 \mu \mathrm{M})-\ldots+\cdots$
B

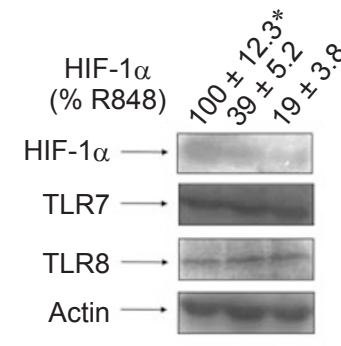

$\operatorname{R848}(0.1 \mu \mathrm{g} / \mathrm{ml})+\quad+$

$\mathrm{DPI}(30 \mu \mathrm{M})-\quad+$

NMMA $(100 \mu \mathrm{M})-\quad+$

D

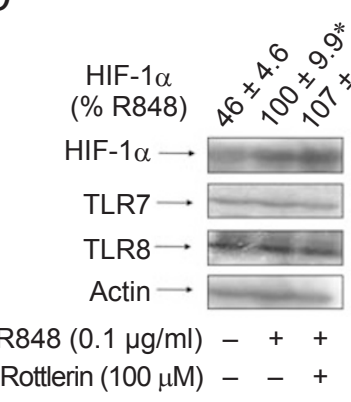

E

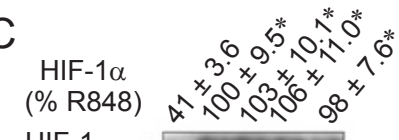

$\mathrm{HIF}-1 \alpha \rightarrow$

TLR7 —

TLR8 $\rightarrow$

Actin $\longrightarrow$

$\operatorname{R848}(0.1 \mu \mathrm{g} / \mathrm{ml})-++++$

ASK1-KM - + + -

$\operatorname{Ly} 294002(30 \mu \mathrm{M})---+$

$\operatorname{PD098059}(10 \mu \mathrm{M})-\ldots+$

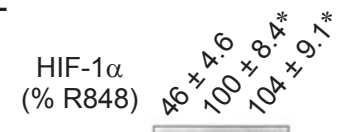

HIF-1 $\alpha \longrightarrow$
TLR7 $\longrightarrow$
TLR8 $\longrightarrow$
Actin $\longrightarrow+\infty$
R848 $(0.1 \mu \mathrm{g} / \mathrm{ml})+++$

IRAK1/4I $(50 \mu \mathrm{M})-\quad+$

Figure 4 Redox- and RNS-dependent mechanisms but not the ASK1/p38 pathway are involved in R848-dependent accumulation of HIF-1 $\alpha$ protein. (A) THP-1 cells were pre-stimulated with respective inhibitors for $1 \mathrm{~h}$ (concentrations are outlined in the figure) and then treated for $4 \mathrm{~h}$ with $0.1 \mu \mathrm{g} / \mathrm{ml} \mathrm{R848.} \mathrm{Accumulation} \mathrm{(western} \mathrm{blot)} \mathrm{and} \mathrm{DNA-binding} \mathrm{activity} \mathrm{(ELISA)} \mathrm{of}$ HIF-1 $\alpha$ protein were assayed. The levels of ROS and RNS assayed were normalised against the amount of protein in the respective samples and expressed in \% control (the amount of ROS/RNS in non-treated THP-1 cells was calculated as $100 \%$ ). (B-E) THP-1 cells were pre-treated with the listed inhibitors at their respective concentrations for $1 \mathrm{~h}$, followed by $4 \mathrm{~h}$ stimulation with $0.1 \mu \mathrm{g} / \mathrm{ml} \mathrm{R848.} \mathrm{In} \mathrm{all} \mathrm{cases} \mathrm{accumulation} \mathrm{of} \mathrm{HIF-1} \alpha$ was measured by western blot. TLR7/8 levels were also monitored and actin staining was used as a protein loading control in all western blot experiments. Digital data are mean values \pm $\mathrm{SD}$ of at least four individual experiments. $* P<0.01 \mathrm{vs}$ control. All western blot data are from one experiment representative of three that gave similar results. Results of densitometric analysis of the western blot data are expressed as mean values \pm SD, where $n=3 ; * P<0.01$ vs control.

by $4 \mathrm{~h}$ stimulation with $0.1 \mu \mathrm{g} / \mathrm{ml} \mathrm{R} 848$. We observed a decrease in R848-mediated RNS production and reduced HIF- $1 \alpha$ accumulation (Figure 4A). Pre-treating the cells with both $30 \mu \mathrm{M}$ DPI and $100 \mu \mathrm{M}$ NMMA produced a more significant reduction in HIF-1 $\alpha$ levels as compared with treatment with either inhibitor alone (Figure 4B). These results imply that both ROS and RNS are involved in HIF- $1 \alpha$ accumulation during R848-induced signaling.

It has been recently shown that apoptosis signal regulating kinase 1 (ASK1)-activated p38 MAP kinase contributes to HIF- $1 \alpha$ stabilisation during LPS-induced
TLR4 signaling [6]. To investigate the role of this pathway in R848-induced TLR7/8-mediated HIF- $1 \alpha$ accumulation, we either transfected the cells with $2.5 \mu \mathrm{g} / \mathrm{ml}$ dominant-negative form of ASK1 (ASKI-KM) or pretreated them for $1 \mathrm{~h}$ with $10 \mu \mathrm{M}$ SB203580 (p38 inhibitor), followed by $4 \mathrm{~h}$ of stimulation with $0.1 \mu \mathrm{g} / \mathrm{ml} \mathrm{R} 848$. In both cases there was no effect on HIF- $1 \alpha$ accumulation (Figure 4A and 4C), suggesting that the ASK1/p38 pathway does not play any role in R848-induced HIF-1 $\alpha$ accumulation.

In addition, the roles of PI3-K (shown to be activated 
by TLR downstream signaling [18]), ERK (known to stimulate NOS activation in macrophages [19]) and $\mathrm{PKC} \delta$ (found to play a role in Nox assembly in zymosanactivated human monocytes [20]) in R848-induced TLR7/8 signaling were investigated. Cells were pretreated with $30 \mu \mathrm{M}$ Ly294002 (PI3-K inhibitor), $10 \mu \mathrm{M}$ PD098059 (ERK inhibitor) and $20 \mu \mathrm{M}$ rottlerin (PKC $\delta$ inhibitor), followed by $4 \mathrm{~h}$ of stimulation with $0.1 \mu \mathrm{g} / \mathrm{ml}$ R848. These inhibitors had no effect on R848-induced HIF- $1 \alpha$ accumulation (Figure 4C and 4D).

IL-1 receptor-associated kinases 1 and 4 (IRAK1/4) activated by the MyD88 pathway are also known to phosphorylate $\mathrm{p} 47_{\text {phox }}$, resulting in Nox assembly and activation [12]. To investigate whether these kinases impact TLR7/8-mediated ROS production, we exposed THP1 cells to $50 \mu \mathrm{M}$ IRAK1/4 inhibitor, followed by $4 \mathrm{~h}$ stimulation with $0.1 \mu \mathrm{g} / \mathrm{ml}$ R848. No effect was observed after $4 \mathrm{~h}$ (Figure 4E). However, IRAK 1/4 may have an effect during the later stages of the signaling process, and we have investigated this further.

None of the inhibitors used had any effect on the levels of TLR 7 and 8 in THP-1 cells (Figure 4).

To study the dynamics of activation, production and involvement of ROS/RNS in accumulation of HIF- $1 \alpha$ protein, we pre-treated the cells for $1 \mathrm{~h}$ with $30 \mu \mathrm{M}$ genistein (tyrosine kinase inhibitor), $30 \mu \mathrm{M} \mathrm{U} 73122$ (PLC$1 \gamma$ inhibitor), $70 \mathrm{nM}$ Gö6983 (PKC $\alpha / \beta$ inhibitor), $30 \mu \mathrm{M}$ DPI (Nox inhibitor), $50 \mu \mathrm{M}$ IRAK1/4 inhibitor, $1 \mathrm{mM}$ NAC (the ROS scavenger) and $100 \mu \mathrm{M}$ NMMA (NOS inhibitor), followed by $16 \mathrm{~h}$ stimulation with $0.1 \mu \mathrm{g} /$ $\mathrm{ml}$ R848. All the inhibitors decreased ROS generation induced by R848. NMMA inhibited R848-induced RNS production (Figure 4). In addition, all inhibitors reduced accumulation of HIF-1 $\alpha$ protein. However, the effect of genistein, U73122 and Gö6983 was lower than that observed after $4 \mathrm{~h}$ exposure to R848 (Figure 5). On the other hand, the IRAK1/4 inhibitor caused a clear reduction in R848-induced HIF- $1 \alpha$ accumulation. This means that at later stages of TLR7/8 signaling, IRAK1/4 (activated in a Btk-PLC- $1 \gamma$-PKC $\alpha / \beta$-independent manner) are important for TLR7/8-mediated ROS generation, which is critical for the accumulation of HIF- $1 \alpha$ protein. None of the inhibitors affected the levels of TLR7/8 (Figure 5).

The concentrations of the inhibitors used were selected based on data available in the literature and on our own experiments, in which we have found that the concentrations used are functional in THP-1 cells [6] and do not affect the viability of the cells as analysed by the MTS test. Successful transfection of the dominant-negative form of ASK1 and its functionality were verified by western analysis and by the measurement of the kinase activity of ASK1, respectively [6] (data not shown).
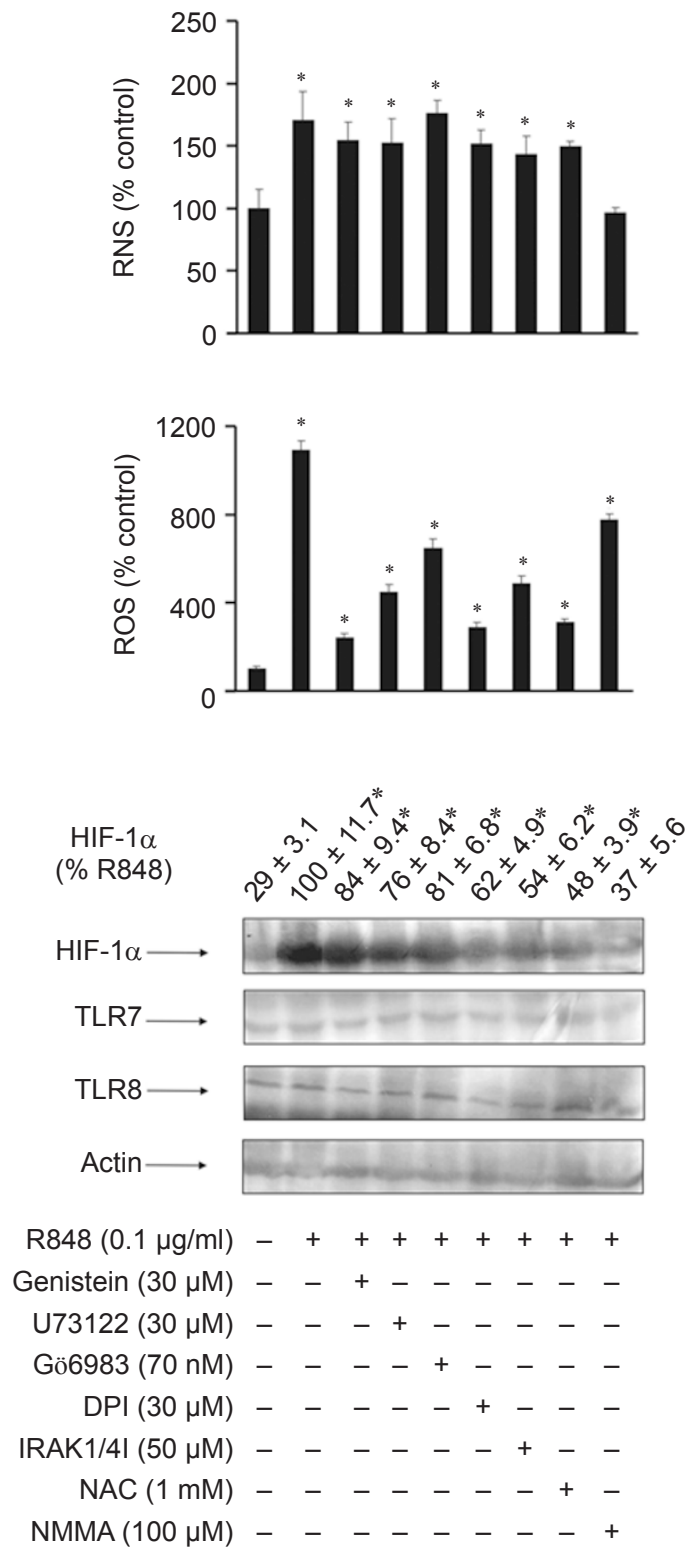

Figure 5 RNS and ROS are needed to maintain R848-dependent TLR7/8-mediated HIF-1 $\alpha$ accumulation at the late stages of signaling. THP-1 cells were pre-treated with respective inhibitors for $1 \mathrm{~h}$ (concentrations are outlined in the figure) and then stimulated for $16 \mathrm{~h}$ with $0.1 \mu \mathrm{g} / \mathrm{ml}$ R848. Accumulation (western blot) and DNA-binding activity (ELISA) of HIF-1 $\alpha$ protein were assayed. TLR7/8 levels were also monitored and actin staining was used as a protein loading control in all western blot experiments. The levels of ROS and RNS assayed were normalised against the amount of protein in the respective samples and expressed in \% control (the amount of ROS/RNS in non-treated THP-1 cells was calculated as $100 \%$ ). Digital data are mean values $\pm \mathrm{SD}$ of at least four individual experiments. $* P<0.01$ vs control. All western blot data are from one experiment representative of three that gave similar results. Results of densitometric analysis of the western blot data are expressed as mean values \pm $\mathrm{SD}$, where $n=3 ; * P<0.01$ vs control. 

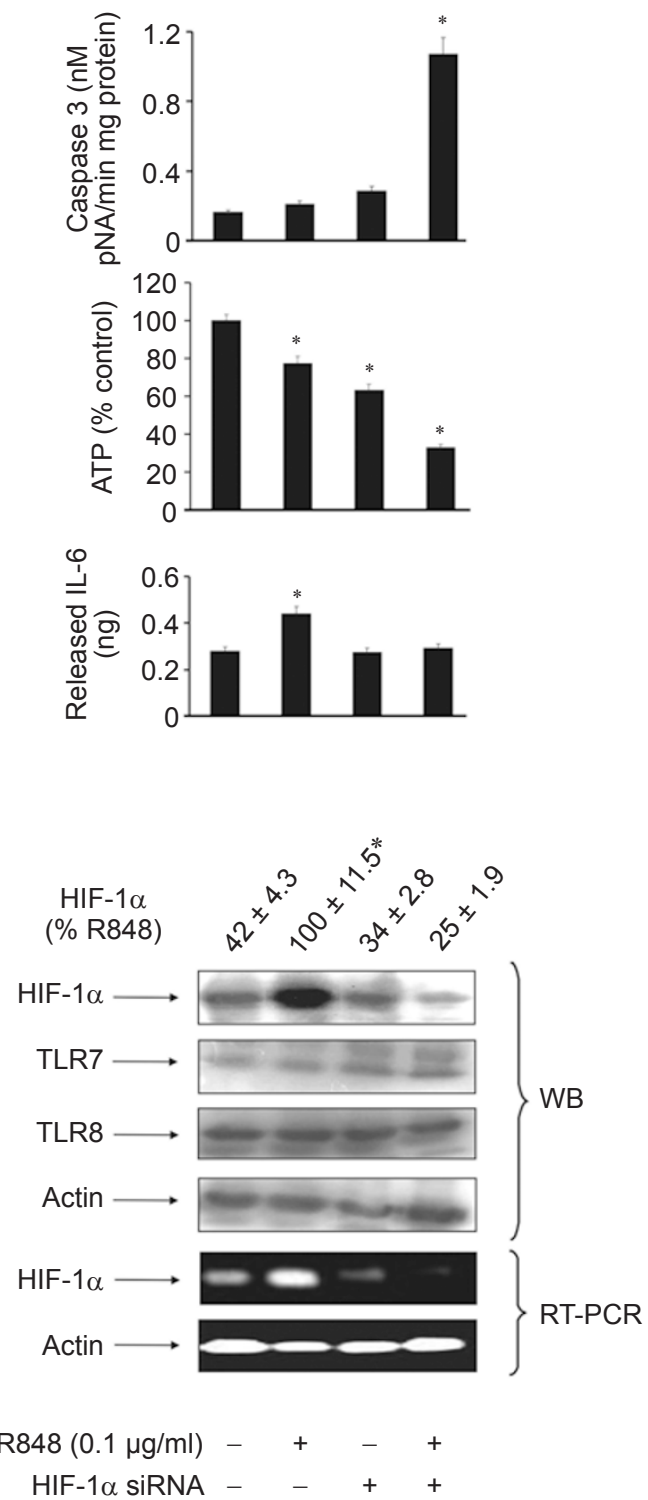

B

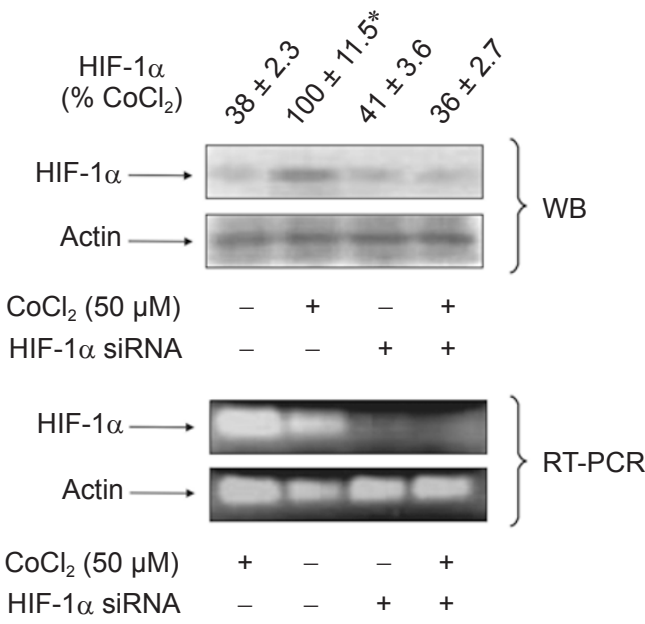

$H I F-1 \alpha$ protein protects THP-1 cells against R848-induced ATP depletion and promotes cell survival supporting IL-6 production

To investigate the role of HIF-1 $\alpha$ in TLR7/8 signaling, we utilised siRNA to knock down this protein. Western blot and RT-PCR confirmed that HIF-1 $\alpha$ was successfully knocked down (Figure 6A). Furthermore, the siRNA used was able to attenuate expression of HIF-1 $\alpha$ induced by a known stabiliser, cobalt chloride (Figure 6B). Upon exposure of HIF-1 $\alpha$ knockdown THP-1 cells to $0.1 \mu \mathrm{g} /$ $\mathrm{ml} \mathrm{R} 848$ for $16 \mathrm{~h}$, a strong increase in caspase 3 activity was observed along with a dramatic depletion of ATP compared with normal THP-1 cells. IL-6 levels were significantly lower than those observed in normal THP1 cells treated with R848 (Figure 6A). To investigate the dynamics of these processes, normal and HIF-1 $\alpha$ knockdown THP-1 cells (in the presence and absence of extracellular ATP) were treated with $0.1 \mu \mathrm{g} / \mathrm{ml} \mathrm{R} 848$ for 2, 4, 8 and $16 \mathrm{~h}$ (Figure 7). IL-6 and TNF $\alpha$ production, caspase 3 activity and ATP concentration were measured. Caspase 3 activity in THP-1 knockdown cells was dramatically increased after $8 \mathrm{~h}$ of R848 treatment, and after $16 \mathrm{~h}$ there was an almost 10 -fold increase in caspase 3 activity compared with normal THP-1 cells stimulated with R848. Similarly, a strong reduction in production of IL- 6 and TNF $\alpha$ was observed in HIF- $1 \alpha$ knockdown

Figure 6 HIF-1 $\alpha$ protein protects THP-1 cells against R848-induced ATP depletion and promotes cell survival supporting IL-6 production. (A) HIF-1 $\alpha$ protein expression in THP-1 cells was knocked down by transfection with specific siRNA. Normal and HIF-1 $\alpha$ knockdown THP-1 cells were exposed to $0.1 \mu \mathrm{g} / \mathrm{ml} \mathrm{R848}$ for $16 \mathrm{~h}$. Accumulation of HIF-1 $\alpha$ protein and its mRNA levels were measured by western blot and RT-PCR, respectively. In addition, caspase 3 activity, the concentration of intracellular ATP and IL- 6 production were also measured. The levels of ATP assayed were normalised against the amount of protein in the respective samples and expressed in \% control (the amount of ATP in non-treated THP-1 cells was calculated as $100 \%)$. The absolute values representing the quantities of the IL- 6 released are expressed in ng. TLR7/8 levels were also monitored. (B) To verify that the siRNA used could attenuate expression of $\mathrm{HIF}-1 \alpha$ protein induced by the known stabiliser cobalt chloride, we performed a similar exposure of the normal and HIF-1 $\alpha$ knockdown THP-1 cells to $50 \mu \mathrm{M} \mathrm{CoCl}_{2}$. Accumulation of HIF- $1 \alpha$ protein and its mRNA levels were measured by western blot and RT$\mathrm{PCR}$, respectively. Actin staining was used as a protein loading control in all western blot experiments. Digital data are mean values \pm SD of at least four individual experiments. ${ }^{*} P<0.01$ vs control. All western blot and RT-PCR data are from one experiment representative of three that gave similar results. Results of densitometric analysis of the western blot data are expressed as mean values $\pm \mathrm{SD}$, where $n=3 ; * P<0.01$ vs control. 

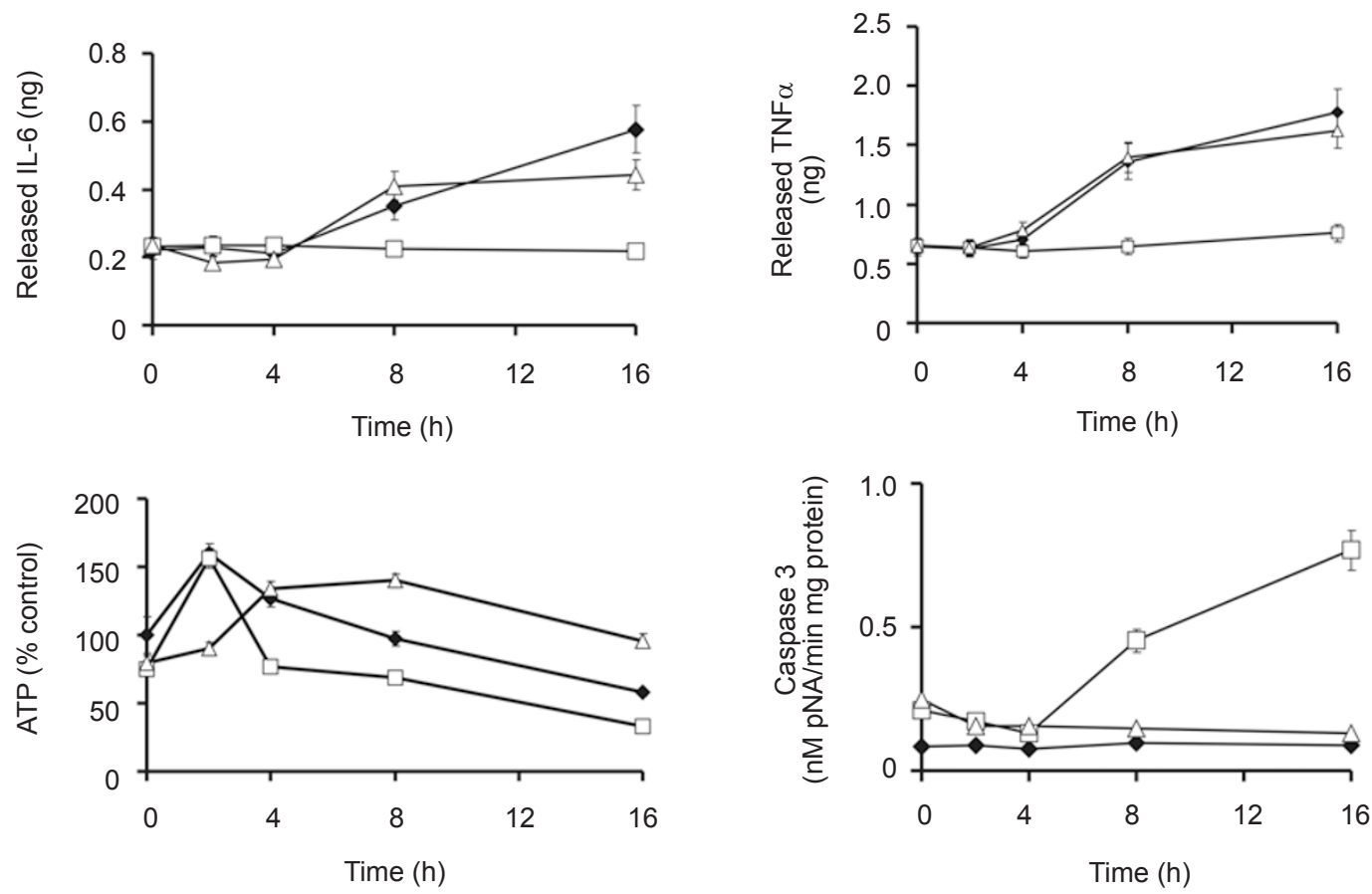

Figure 7 Dynamics of R848-induced changes in IL-6 and TNF $\alpha$ production, ATP levels and caspase 3 activity in normal and HIF-1 $\alpha$ knockdown THP-1 cells in the absence or presence of extracellular ATP. Normal $(\bullet)$ and HIF-1 $\alpha$ knockdown (in the absence $(\square)$ and presence $(\triangle$ ) of extracellular ATP) THP-1 cells were exposed to $0.1 \mu \mathrm{g} / \mathrm{ml} \mathrm{R848} \mathrm{for} 2,4,8$ and $16 \mathrm{~h}$. Release of IL- 6 and TNF $\alpha$, concentration of intracellular ATP and activity of caspase 3 were analysed. The levels of ATP assayed were normalised against the amount of protein in the respective samples and expressed in \% control (the amount of ATP in non-treated THP-1 cells was calculated as 100\%). The absolute values representing the quantities of the cytokines released are expressed in $\mathrm{ng}$. Digital data are mean values $\pm \mathrm{SD}$ of at least four individual experiments. $* P<0.01$ vs control.

THP-1 cells compared with normal cells when treated with R848. Time-dependent depletion of ATP in THP1 knockdown cells was obvious. Treatment of THP-1 knockdown cells with extracellular ATP restored ATP levels, and also reversed the effects listed above, leading to restoration of IL- 6 and TNF $\alpha$ production and an attenuation of caspase-3 activity (Figure 7). This suggests that HIF-1 $\alpha$ is critical for the protection of THP-1 cells against TLR7/8-induced depletion of ATP, which might support cell survival and the production of pro-inflammatory cytokines IL- 6 and $\mathrm{TNF} \alpha$.

\section{Discussion}

Inflammatory reactions induced by ssRNA viruses via TLRs 7 and 8 lead to cellular stress, which is associated with activation of dozens of ATP-dependent enzymes. This increases consumption of available oxygen and makes the effector leukocytes dependent on glycolysis $[1,21]$. However, the basic biochemical mechanisms involved in survival of these cells are not clear. In this study we have investigated a possible role for HIF-1 $\alpha$ protein in cellular adaptation to stress and production of pro-inflammatory cytokines during TLR7/8 signaling.

First of all, we asked whether ligand-induced TLR7/8 downstream pathways lead to the accumulation of HIF$1 \alpha$ protein. It was found that both $\mathrm{R} 848$, the synthetic ligand of TLR7/8, and the uridine-rich fragment of the HXB2 region of HIV-1 induce accumulation of HIF-1 $\alpha$ protein in THP-1 human myeloid macrophages. This correlated with an increase in the mRNA and DNA-binding activity of HIF- $1 \alpha$ in these cells, suggesting that TLR7/8 downstream signaling induces expression/accumulation of transcriptionally active HIF- $1 \alpha$.

Using pharmacological inhibitors we have shown the involvement of Nox-derived ROS as well as RNS in TLR7/8-induced accumulation of HIF- $1 \alpha$ protein (see Results). During TLR7/8 signaling, Nox gets activated in the following way. Bruton's tyrosine kinase (Btk) as well as other tyrosine kinases stimulate recruitment of MyD88 adaptor proteins required for TLR7/8 downstream signaling [22]. In addition, Btk and other tyrosine kinases 
activate PI-specific PLC- $1 \gamma$ known to release DAG and $\mathrm{PI}$, which increases the intracellular $\mathrm{Ca}^{2+}$ concentration $[13,16]$. Both DAG and $\mathrm{Ca}^{2+}$ activate PKC $\alpha / \beta$ known to phosphorylate the $\mathrm{p} 47_{\text {phox }}$ subunit of Nox $[16,17]$, leading to its activation and subsequent ROS production. Inhibiting each step of this pathway and NAC-dependent scavenging of ROS attenuated both R848-induced ROS production and accumulation of HIF- $1 \alpha$. Similarly, NMMA-dependent inhibition of RNS production also affected stabilisation of HIF-1 $\alpha$ during R848-induced TLR7/8 signaling. In contrast, ROS but not RNS has been previously reported to be involved in the accumulation of HIF- $1 \alpha$ during LPS-induced TLR4 downstream signaling [6]. In the latter case HIF-1 $\alpha$ protein had to be phosphorylated by p38 MAP kinase, which was activated in an ASK1-dependent manner. Using the dominantnegative form of ASK1 and SB203580 (a specific inhibitor of p38), we have shown that this pathway does not influence TLR7/8-dependent accumulation of HIF-1 $\alpha$ protein. Thus, TLR4 and TLR7/8 appear to utilize different mechanisms for HIF- $1 \alpha$ accumulation.

The PI3 kinase-downstream pathway, which in theory could influence expression/accumulation of HIF-1 $\alpha$, did not in any way affect the stabilisation induced by $\mathrm{R} 848$ in a TLR7/8-dependent manner.

The activation of Nox appeared to occur via varying mechanisms at the early vs the later stages of R848-induced TLR7/8 signaling. Genistein, U73122 and Gö6983 all caused a severe reduction in HIF- $1 \alpha$ levels during the early stages of TLR7/8 signaling, but had a much milder effect on HIF-1 $\alpha$ levels later on. In contrast, the inhibition of IRAK1/4, which were recently reported to phosphorylate $\mathrm{p} 47_{\text {phox }}$ and therefore to activate Nox [12], was found to attenuate R848-induced ROS production/HIF$1 \alpha$ accumulation at later stages of TLR7/8 signaling, but had absolutely no effect early on. This implies that the Btk-PLC- $1 \gamma$-PKC $\alpha / \beta$ pathway is needed for $\mathrm{p} 47_{\text {phox }}$ activation at the early stages of R848-induced TLR7/8 signaling, but at later stages IRAK1/4 activation of $\mathrm{p} 47_{\text {phox }}$ becomes more crucial.

The experiments with HIF-1 $\alpha$ knockdown (achieved with the help of specific siRNA) THP-1 cells clearly demonstrated that HIF-1 $\alpha$ protein is critical for protection of the cells against R848-induced TLR7/8-dependent depletion of ATP and therefore against programmed death. This protection was found crucial for production of IL- 6 and TNF $\alpha$. When the level of ATP was restored by application of extracellular ATP, HIF- $1 \alpha$ knockdown did not affect cell survival (as based on the results of the caspase 3 assay) or production of IL-6/TNF $\alpha$. These data correspond to recent findings concerning the role of HIF$1 \alpha$ protein in LPS-induced TLR4-mediated responses
[11]. Therefore, one could possibly conclude that both membrane-associated (TLR4) and endosomal (TLR7/8) TLRs induce accumulation/activation of HIF-1 $\alpha$ protein although different mechanisms are employed. This accumulation might be important for the support of cell survival as it protects the effector cells against depletion of ATP, and might thus contribute to the production of proinflammatory cytokines.

\section{Materials and methods}

\section{Materials}

Medium, fetal calf serum and supplements, caspase 3 colorimetric assay kit, DOTAP transfection reagent, enhanced avian HS RT-PCR kit, GenElute ${ }^{\mathrm{TM}}$ mammalian total RNA miniprep kit, and all pharmacological kinase/phosphatase inhibitors, HIF-1 $\alpha$-specific siRNA and the uridine-rich ssRNA fragment of the HXB2 region of HIV-1 (the sequence is UUG UUA AGU GUU UCA AUU GU [23]) were purchased from Sigma (Suffolk, UK). Maxisorp ${ }^{\mathrm{TM}}$ microtitre plates were obtained from Nunc (Roskilde, Denmark). The ELISA-based assay kit for detection of IL-6 was bought from R\&D Systems (Abingdon, UK). Mouse monoclonal antibody to HIF-1 $\alpha$, mouse monoclonal antibody to TLR7, rabbit monoclonal antibodies to ASK1 and TLR8, mouse monoclonal antibody to $\beta$ actin, as well as rabbit polyclonal HRP-labelled antibody to mouse IgG and goat polyclonal HRP-labeled antibody to rabbit IgG were from Abcam (Cambridge, UK). All other chemicals were of the highest grade of purity and commercially available.

\section{Cell culture}

THP-1 human leukemia monocytic macrophages were purchased from the European Collection of Cell Cultures (Salisbury, UK). Cells were grown in RPMI 1640 media supplemented with $10 \%$ fetal calf serum, penicillin $(50 \mathrm{IU} / \mathrm{ml})$ and streptomycin sulphate $(50 \mu \mathrm{g} / \mathrm{ml})$.

\section{Plasmids}

The plasmid encoding hemagglutinin (HA)-tagged human ASK1 with kinase-dead domain (dominant-negative form), ASK1KM, was a kind gift of Professor Ichijo (University of Tokyo, Tokyo, Japan). The plasmid was amplified in Escherichia coli XL10 Gold $^{\circledR}$ (Stratagene Europe, Amsterdam, The Netherlands) and purified using GenElute ${ }^{\mathrm{TM}}$ plasmid purification kit according to the manufacturer's protocol. Purified plasmids were transfected into THP-1 cells using DOTAP transfection reagent according to the manufacturer's protocol.

\section{Transfer of SsRNA fragment and HIF-1 $\alpha$ siRNA to THP-1 cells}

siRNA specific to HIF-1 $\alpha$ was selected as described before [24]. siRNA as well as the ssRNA fragment were transfected into THP-1 cells using DOTAP transfection reagent [11] according to the manufacturer's protocol.

\section{Western blot analysis}

HIF-1 $\alpha$, TLR7 and TLR8 proteins were detected by western blot analysis. Briefly, $100 \mu \mathrm{g}$ of cell lysate proteins were added to the same volume of $2 \times$ sample buffer $(125 \mathrm{mM}$ Tris- $\mathrm{HCl}, 2 \%$ 
SDS, $10 \%$ glycerin, $1 \mathrm{mM}$ DTT, $0.002 \%$ bromophenol blue, $\mathrm{pH}$ 6.9) and boiled for $5 \mathrm{~min}$. Proteins were resolved on 7.5\% SDSpolyacrylamide gels and blotted to nitrocellulose membrane. Molecular weights were calibrated in proportion to the running distance of rainbow markers. Transblots were washed twice with Tris-buffered saline (TBS, $50 \mathrm{mM}$ Tris- $\mathrm{HCl}, 140 \mathrm{mM} \mathrm{NaCl}, \mathrm{pH}$ 7.3 ) containing $0.1 \%$ Tween 20 before blocking unspecific binding with TBS plus $5 \%$ skim milk for $1 \mathrm{~h}$. The primary antibody diluted with TBS plus 5\% milk was added and incubated for 60 minutes at room temperature. Afterwards, nitrocellulose membranes were washed five times for 15 min with TBS containing $0.1 \%$ Tween 20 . For protein detection, blots were incubated with the respective secondary antibodies conjugated with horseradish peroxidase ( $1: 1000$ in TBS plus $5 \%$ milk) for $60 \mathrm{~min}$, followed by ECL detection. The western blot data for HIF-1 $\alpha$ protein were analysed by densitometry and normalised against the respective levels of actin.

\section{Determination of HIF-1 DNA-binding activity}

HIF-1 DNA-binding activity was measured by a method similar to the one described recently with our modifications $[6,8]$. A 96-well Maxisorp ${ }^{\mathrm{TM}}$ microtitre plate was coated with streptavidin and blocked with BSA as described before. A volume of $2 \mathrm{pmol} /$ well biotinylated 2HRE-containing oligonucleotide was immobilised by $1 \mathrm{~h}$ incubation at room temperature. The plate was then washed five times with TBST buffer $(10 \mathrm{mM}$ Tris-HCl, $\mathrm{pH} 8.0$, $150 \mathrm{mM} \mathrm{NaCl}, 0.05 \%$ Tween-20), followed by $1 \mathrm{~h}$ incubation with $20 \mu \mathrm{l} /$ well of cell lysate at room temperature. The plate was again washed five times with TBST buffer and mouse anti-HIF$1 \alpha$ antibody(1:1 000 in TBS plus $2 \%$ BSA) was added. After $1 \mathrm{~h}$ of incubation at room temperature the plate was washed five times with TBST buffer and incubated with 1:1 000 HRP-labelled rabbit anti-mouse IgG in TBST buffer. After extensive washing with TBST, the bound secondary antibody was detected by the peroxidase reaction (ortho-phenylenediamine $/ \mathrm{H}_{2} \mathrm{O}_{2}$, Kem-En-Tek Diagnostics, Copenhagen, Denmark). The reactions were quenched after 10 min with an equal volume of $1 \mathrm{M} \mathrm{H}_{2} \mathrm{SO}_{4}$ and the colour development was measured in a microplate reader as the absorbance at $492 \mathrm{~nm}$. DNA-binding activity of HIF-1 was calculated as a percentage of the value obtained when analysing lysates of non-treated cells (control).

\section{Measurement of HIF-1 $\alpha$ and VEGF $m R N A$ by RT-PCR}

Total RNA was isolated using GenElute ${ }^{\mathrm{TM}}$ mammalian total RNA miniprep kit, followed by HIF- $1 \alpha$ mRNA reverse transcriptase-polymerase chain reaction (RT-PCR) [6, 25]. Primer selection was as follows: HIF-1 $\alpha$, 5'-CTC AAA GTC GGA CAG CCT CA-3', 5'-CCC TGC AGT AGG TTT CTG CT-3'; VEGF, 5'-GTA TAA GTC CTG GAG CGT-3', 5'-CTC GGA GGG AGT CCC AAA-3'; actin, 5'-TGA CGG GGT CAC CCA CAC TGT GCC CAT CTA-3', 5'-CTA GAA GCA TTT GCG GTC GAC GAT GGA GGG-3'. Amplification program was as follows: $95^{\circ} \mathrm{C}, 30 \mathrm{~s}$; $56{ }^{\circ} \mathrm{C}, 30 \mathrm{~s} ; 72{ }^{\circ} \mathrm{C}, 1 \mathrm{~min} ; 20$ cycles; $72{ }^{\circ} \mathrm{C}, 10 \mathrm{~min}$. Products were separated on $2 \%$ agarose gels and visualized with ethidium bromide.

\section{Measurement of caspase 3 activity}

The activity of caspase 3 was assayed by the colorimetric method based on the hydrolysis of the peptide substrate acetylAsp-Glu-Val-Asp-p-nitroanilide (Ac-DEVD-pNA) according to the manufacturer's protocol.

\section{Detection of ROS and RNS generation}

Generation of ROS was analysed by luminol-dependent chemiluminescence as described before [26]. RNS production was detected by the Griess assay [27].

\section{Detection of intracellular ATP}

This was analysed using a luminometric kit (Sigma) according to the manufacturer's protocol.

\section{Measurement of IL-6 and TNF $\alpha$ production}

Production of IL- 6 and TNF $\alpha$ by THP-1 cells were analysed by ELISA using R\&D kits according to the manufacturer's protocols.

\section{Cell viability assay}

Viability of THP-1 cells was detected using the MTS cell viability assay kit (Promega) according to the manufacturer's protocol.

\section{Statistical analysis}

Each experiment was performed at least three times and statistical analysis was done using the two-tailed Student's $t$-test. The statistical probability $(P)$ was expressed as $* P<0.01$. The normal distribution of data was checked.

\section{Acknowledgments}

We thank Professor Hidenori Ichijo (University of Tokyo, Japan) for the gift of reagents. This work was supported by the startup grant provided by the Medway School of Pharmacy, University of Kent (UK).

\section{References}

1 Beutler B. Inferences, questions and possibilities in Toll-like receptor signalling. Nature 2004; 430:257-263.

2 Akira S, Takeda K. Toll-like receptor signalling. Nat Rev Immunol 2004; 4:499-511.

3 Nishiya T, DeFranco AL. Ligand-regulated chimeric receptor approach reveals distinctive subcellular localization and signaling properties of the Toll-like receptors. J Biol Chem 2004; 279:19008-19017.

4 Hayashi F, Means TK, Luster AD. Toll-like receptors stimulate human neutrophil function. Blood 2003; 102:2660-2669.

5 Mosser DM. The many faces of macrophage activation. $J$ Leukoc Biol 2003; 73: 209-212.

6 Sumbayev VV. LPS-induced Toll-like receptor 4 signalling triggers cross-talk of apoptosis signal-regulating kinase 1 (ASK1) and HIF-1alpha protein. FEBS Lett 2008; 582:319326.

7 Semenza GL. HIF-1 and tumor progression: pathophysiology and therapeutics. Trends Mol Med 2002; 8:S62-S67.

8 Sumbayev VV, Yasinska IM. Regulation of MAP kinasedependent apoptotic pathway: implication of reactive oxygen and nitrogen species. Arch Biochem Biophys 2005; 436:406412.

9 Ivan M, Kondo K, Yang H, et al. HIFalpha targeted for VHLmediated destruction by proline hydroxylation: implications for O2 sensing. Science 2001; 292:464-468.

10 Walmsley SR, Cadwallader KA, Chilvers ER. The role of 
HIF-1alpha in myeloid cell inflammation. Trends Immunol 2005; 26:434-439.

11 Lall H, Coughlan K, Sumbayev VV. HIF-1alpha protein is an essential factor for protection of myeloid cells against LPSinduced depletion of ATP and apoptosis that supports Toll-like receptor 4-mediated production of IL-6. Mol Immunol 2008; 45:3045-3049.

12 Pacquelet S, Johnson JL, Ellis BA, et al. Cross-talk between IRAK-4 and the NADPH oxidase. Biochem J 2007; 403:451461.

13 Gray P, Dunne A, Brikos C, Jefferies CA, Doyle SL, O’Neill LA. MyD88 adapter-like (Mal) is phosphorylated by Bruton's tyrosine kinase during TLR2 and TLR4 signal transduction. $J$ Biol Chem 2006; 281:10489-10495.

14 Sochorova K, Horvath R, Rozkova D, et al. Impaired Tolllike receptor 8-mediated IL-6 and TNF-alpha production in antigen-presenting cells from patients with X-linked agammaglobulinemia. Blood 2007; 109:2553-2556.

15 Schwartzberg PL. Amplifying Btk's signal. Immunity 2003; 19:634-636.

16 Siow YL, Au-Yeung KK, Woo CW, O K. Homocysteine stimulates phosphorylation of NADPH oxidase p47phox and p67phox subunits in monocytes via protein kinase Cbeta activation. Biochem J 2006; 398:73-82.

$17 \mathrm{He} \mathrm{H}$, Genovese KJ, Nisbet DJ, Kogut MH. Involvement of phosphatidylinositol-phospholipase $\mathrm{C}$ in immune response to Salmonella lipopolysaccharide in chicken macrophage cells (HD11). Int Immunopharmacol 2006; 6:1780-1787.

18 Kuo CC, Lin WT, Liang CM, Liang SM. Class I and III phosphatidylinositol 3'-kinase play distinct roles in TLR signaling pathway. J Immunol 2006; 176:5943-5949.
19 Kim SH, Kim J, Sharma RP. Inhibition of p38 and ERK MAP kinases blocks endotoxin-induced nitric oxide production and differentially modulates cytokine expression. Pharmacol Res 2004; 49:433-439.

20 Zhao X, Xu B, Bhattacharjee A, et al. Protein kinase Cdelta regulates p67phox phosphorylation in human monocytes. $J$ Leukoc Biol 2005; 77:414-420.

21 Oda T, Hirota K, Nishi K, et al. Activation of hypoxia-inducible factor 1 during macrophage differentiation. Am J Physiol Cell Physiol 2006; 291:C104-C113.

22 Doyle SL, Jefferies CA, Feighery C, O’Neill LA. Signaling by Toll-like receptors 8 and 9 requires Bruton's tyrosine kinase. J Biol Chem 2007; 282:36953-36960.

23 Meier A, Alter G, Frahm N, et al. MyD88-dependent immune activation mediated by human immunodeficiency virus type 1-encoded Toll-like receptor ligands. J Virol 2007; 81:81808191.

24 Hanze J, Eul BG, Savai R, et al. RNA interference for HIF1alpha inhibits its downstream signalling and affects cellular proliferation. Biochem Biophys Res Commun 2003; 312:571577.

25 Shatrov VA, Sumbayev VV, Zhou J, Brune B. Oxidized lowdensity lipoprotein (oxLDL) triggers hypoxia-inducible factor-1alpha (HIF-1alpha) accumulation via redox-dependent mechanisms. Blood 2003; 101:4847-4849.

26 Kapiszewska M, Cierniak A, Elas M, Lankoff A. Lifespan of etoposide-treated human neutrophils is affected by antioxidant ability of quercetin. Toxicol In Vitro 2007; 21:1020-1030.

27 Cook JA, Kim SY, Teague D, et al. Convenient colorimetric and fluorometric assays for S-nitrosothiols. Anal Biochem 1996; 238:150-158. 